\title{
THE DETERMINATION OF THE TOTAL HEAT ELIMINATED BY THE HUMAN BEING ${ }^{1}$
}

By MARGARET WOODWELL JOHNSTON AND L. H. NEWBURGH

(From the Department of Internal Medicine, Medical School, University of Michigan,

- Ann Arbor)

(Received for publication July 1, 1929)

It is desirable to be able to determine accurately the total energy exchange of human subjects who are to be observed for a number of consecutive days during which a variety of diets may be fed and a certain amount of activity must be permitted. The chamber calorimeter is in general impractical, nor is the average heat production obtained through repeated determination by means of indirect calorimetry satisfactory. We have accordingly taken up the question whether a third method recently brought forward by Benedict and Root (1) could not be modified to meet this need. They have shown that the amount of the "Insensible Perspiration" bears a definite quantitative relationship to the metabolic rate under basal conditions. They obtained the loss of weight per hour of subjects in the basal state by means of a delicate balance, sufficiently large to support the necessary weight; and plotted this against the basal calories for twenty-four hours, obtained by a standard method. By so doing they found that the heat loss for a unit of time is a linear function of the insensible loss of weight for that interval of time. They accordingly concluded that the twenty-four-hour basal heat production could be predicted from the hourly basal insensible loss of weight.

The insensible loss of weight includes of necessity the water vapor eliminated from the body. This vaporization of water is an important mechanism for the removal of heat. If the insensible loss of weight bears a constant relationship to the heat elimination, it is necessary that two conditions be fulfilled: (1) The organism must lose a fixed proportion of its heat by vaporization of water and (2) the weight of

${ }^{1}$ Aided by a grant from The Fellowship Corporation. 
water vapor must bear a fixed relationship to the total insensible loss of weight.

Numerous studies of the proportion of the total heat eliminated, effected through the vaporization of water have been made by means of the calorimeter. Soderstrom and Du Bois (2) point out the difficulties in determining accurately the water vapor given off, in the calorimeter, since the rate of ventilation may not always be sufficient to maintain a constant humidity. They 'state that the error may be as much as 10 per cent. The results they obtained with a group of normal men, some of the same men following the ingestion of food, a group of boys twelve to thirteen years old, and a group of old men,

TABLE 1

Percentage of heat loss effected through vaporization of water (Söderstrom and Du Bois)

\begin{tabular}{|c|c|c|}
\hline \multirow{2}{*}{ Subject } & \multicolumn{2}{|c|}{$\begin{array}{l}\text { Percentage of heat lost by } \\
\text { vaporization }\end{array}$} \\
\hline & Average & Range \\
\hline$\bullet$ & per cent & per cent \\
\hline Normal $(13) \ldots \ldots \ldots \ldots \ldots \ldots \ldots \ldots$ & 24 & $21-28$ \\
\hline Normal-food $(5) \ldots \ldots \ldots \ldots \ldots \ldots \ldots \ldots \ldots \ldots$ & 23 & $21-26$ \\
\hline 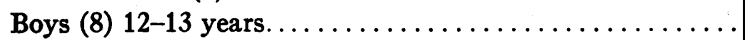 & 27 & $22-32$ \\
\hline Old $\operatorname{men}(6) \ldots \ldots \ldots \ldots \ldots \ldots \ldots \ldots \ldots \ldots \ldots \ldots$ & 27 & 23-29 \\
\hline
\end{tabular}

will be found in table 1. The average percentage of heat lost through the vaporization of water for all groups varied only from 23 to 27 .

Likewise, Benedict (3) found in 43 observations of ten individuals in the basal state, an average value of 22 per cent, with a variation of 19 to 30 per cent. He obtained the same value in ten experiments carried out with twenty individuals after the ingestion of food, with approximately the same variation.

Levine and Wilson $(4,5)$ studied six normal children and found a variation of 24 to 29 , per cent with an average value of 24 per cent of their total calories lost through the vaporization of water. In the case of four normal and six marantic infants, they found 26.5 and 25.6 per cent respectively. Their range for the whole group was only from 25 to 30 per cent. These investigators point out that "Despite the enormous differences in metabolic rates in the age periods from 
infancy to adult life, apparently a definite and unvarying fraction of the total amount of heat produced by all subjects was removed from the body by vaporization of water through skin and lungs, (average of 26 per cent)."

Since Isenschmid (6) has defined the insensible loss of weight as equal to the weight of the water vaporized plus the carbon dioxide excreted, minus the oxygen absorbed, it is clear that one may calculate the proportion of the total heat loss effected by the vaporization of water, if the insensible loss of weight, the carbon dioxide output, oxygen absorption and total heat production are known.

\section{TABLE 2}

Relation between heat lost by vaporization of water and total loss of heat in the basal state

\begin{tabular}{c|c|c|c|c|c|c|c}
\hline $\begin{array}{c}\text { Insensible } \\
\text { loss }\end{array}$ & $\mathrm{CO}_{2}$ & $\mathrm{O}_{2}$ & $\begin{array}{c}\text { Insensible } \\
\text { water }\end{array}$ & \multicolumn{2}{|c|}{ Total heat } & \multirow{2}{*}{ Heat loss by vaporization } \\
\hline grams per howr & $\begin{array}{c}\text { grams per } \\
\text { howr }\end{array}$ & $\begin{array}{c}\text { grams per } \\
\text { howr }\end{array}$ & $\begin{array}{c}\text { grams per } \\
\text { hour }\end{array}$ & $\begin{array}{c}\text { calories per } \\
24 \text { hours }\end{array}$ & $\begin{array}{c}\text { Galories per } \\
24 \text { hours }\end{array}$ & $\begin{array}{c}\text { calories per } \\
24 \text { hours }\end{array}$ & per cent \\
28.9 & 19.16 & 17.06 & 26.8 & 1,382 & 1,372 & 373 & 27 \\
26.6 & 17.83 & 16.29 & 25.1 & 1,312 & 1,300 & 349 & 27 \\
28.3 & 17.53 & 16.90 & 27.7 & 1,347 & 1,354 & 386 & 28 \\
23.9 & 16.36 & 15.54 & 24.1 & 1,243 & 1,242 & 336 & 27 \\
27.1 & 17.34 & 16.62 & 26.4 & 1,326 & 1,315 & 368 & 28 \\
29.2 & 17.59 & 17.28 & 28.9 & 1.372 & 1,382 & 402 & 28 \\
26.7 & 17.31 & 15.62 & 25.2 & 1,285 & 1,301 & 351 & 27 \\
25.3 & 16.38 & 15.45 & 24.4 & 1,237 & 1,257 & 340 & 27 \\
27.5 & 17.11 & 16.44 & 26.8 & 1,312 & 1,327 & 373 & 28 \\
\hline
\end{tabular}

To do this, we determined the basal heat production, the oxygen absorption, and the carbon dioxide output by means of the Tissot method. The basal insensible loss of weight was obtained by means of a large balance on the same day or alternate days. The weight of the water vaporized was calculated from the equation of Isenschmid. These data for a normal subject will be found in table 2 . It will be seen that the heat lost by the vaporization of water $(0.58 \times$ weight of water vapor) bears a constant relationship ( 27 to 28 per cent) to the heat production, and therefore to the heat elimination, since the two are equal under these conditions.

Our studies present further evidence that the organism tends to 
lose a fixed proportion of its heat through the vaporization of water. It is therefore true that the first condition necessary for constant relationship between the insensible loss of weight and the total heat elimination exists. ${ }^{2}$

The second condition postulated, i.e., that the weight of the water vapor must bear a fixed relationship to the total insensible loss of weight will now be considered. From Isenschmid's equation, it is obvious that this relationship can only be disturbed by variation in the difference between the weight of carbon dioxide excreted and oxygen absorbed. In the basal state, the respiratory quotient and consequently this difference, except in a few cases, varies but little. Therefore, for individuals in the basal state, both conditions are fulfilled, and the insensible loss of weight must bear a definite relationship to the total heat elimination. It is obvious that a marked departure from the usual basal quotient will entail a small error.

The advantage of extending this simple method for the determination of total energy expenditure to consecutive twenty-four hour periods in the case of individuals who are taking food and voiding excreta, is obvious.

On theoretical grounds, two major objections present themselves. First, if the tótal heat elimination is to be used as a measure of the total energy expenditure, the performance of mechanical work must be avoided or measured. Second, it will be recalled that the validity of this method rests upon the constancy of the relationship between the total insensible loss of weight, and the weight of water vaporized. From Isenschmid's equation, it is obvious that this relation is effected by variations in the difference between carbon dioxide excreted and the oxygen absorbed. In other words, the nature of the metabolic mixture will effect this relationship. The degree to which it is effected may easily be calculated as follows: An hypothetical individual has a basal metabolic rate of 2025 calories per twenty-four-hours. The respiratory quotient is 0.82 , under these conditions he will absorb 600 grams of oxygen and give off 676 grams of carbon dioxide. The

${ }^{2}$ It will be further seen that these results confirm those of Benedict and Root in that the twenty-four hourly loss of heat predicted from the hourly insensible loss of weight agrees with the twenty-four hourly heat production determined by the Tissot method. 
weight of the water vapor given off may be calculated, since approximately 28 per cent ${ }^{3}$ of the total heat loss is effected in this way. The amount is 978 grams $\left(\frac{2025 \times 0.28}{0.58}\right)$. Therefore, the insensible loss of weight $=978$ grams +676 grams -600 grams which is 1054 grams. When, therefore, the respiratory quotient is 0.82 , the weight of the water vaporized will be 92.8 per cent of the total insensible loss of weight. If the heat production remains the same, but the quotient becomes 1.00 instead of 0.82 , the individual will absorb 573 grams of oxygen and give off 788 grams of carbon dioxide. The insensible water remains the same. Hence, the total insensible loss of weight becomes 1193 grams. In this case, the weight of the water vapor becomes 82 per cent of the total insensible loss of weight.

On the other hand, when the'respiratory quotient is 0.707 , the insensible loss of weight becomes 940 grams and therefore it will be seen that the weight of the water vapor is 104 per cent of the total insensible loss. It is therefore theoretically true that an individual with a heat production of 2025 calories might lose insensibly an amount of weight which varies from 940 grams to 1193 grams. What does this variation signify in terms of predicted heat loss? By consulting the table of Benedict and Root, it will be noted that each increment of one gram of the insensible loss of weight corresponds to thirty-one calories per twenty-four-hours. The maximal variation in the insensible loss of weight for the subject whose heat production was 2025 calories, was 253 grams. This would represent a variation of 315 calories per twenty-four-hours, or 15 per cent of the total heat production. When the usual basal respiratory quotient of 0.82 exists, the maximal variation from it to unity is 8 per cent, and from it to 0.707 , 7 per cent. Since Benedict and Root obtained the data for their table from subjects in the basal state, the respiratory quotients were presumably in the neighborhood of 0.82 . Since neither pure carbohydrate nor fat furnish all the energy for the twenty-four-hour period, the possible error in the extension of Benedict's and Root's values to the twenty-four-hour state would be less than 8 per cent. The probable error is less than 5 per cent, the usual error allowable in other methods of determining energy outgo.

${ }^{3}$ We have used the value obtained by us. 


\section{METHOD}

If it is desired to obtain the weight of the insensible perspiration for twenty-four-hour periods in subjects who are taking food and voiding excreta, allowance must be made for the weight of these materials. Under these circumstances the difference between the subject's weight at the beginning and at the end of the period is not merely the weight of the insensible perspiration; for the second weight of the subject has been "sensibly" increased by the weight of the ingesta and "sensibly" diminished by the weight of the urine and stool. In

TABLE 3

Determination of insensible perspiration for a period of twenty-four hours

\begin{tabular}{|c|c|c|c|}
\hline & grams & & grams \\
\hline First weight of subject......... & 61,695 & Second weight of subject.... & 61,465 \\
\hline Weight of food.............. & 1,615 & Weight of urine.......... & 1,436 \\
\hline \multirow[t]{2}{*}{ Weight of drink.............. } & 715 & Weight of stool. ............ & 102 \\
\hline & 64,025 & & 63,003 \\
\hline
\end{tabular}

First corrected weight.................................... 64,025

Second corrected weight. $\ldots \ldots \ldots \ldots \ldots \ldots \ldots \ldots \ldots \ldots \ldots \ldots \ldots \ldots \ldots, 0,003$

Insensible perspiration $\ldots \ldots \ldots \ldots \ldots \ldots \ldots \ldots \ldots \ldots \ldots \ldots \ldots \ldots, \overline{1,022}$

Hourly insensible perspiration: $\frac{1022}{24}=42.6$

Total calories for the 24 hours $=1800$

order to correct for these factors, the weight of the ingesta was added to the weight of the subject at the beginning of the period, and the combined weight of the urine and stool was added to the weight of the subject at the end of the period. The difference between these corrected weights of the subject now represents the weight of the insensible perspiration for the period. ${ }^{4}$ Table 3 is an example of the application of this procedure for obtaining the total insensible loss

This method of weighing the insensible perspiration, in the case of subjects who were active and taking food, has been used by a number of earlier observers. Since their work has already been discussed in the paper of Benedict and Root (1) it is needless for us to review it again. 
of weight. ${ }^{5}$ The hourly insensible loss is obtained by dividing the total insensible loss by the length of the period expressed in hours. The twenty-four-hour calories, which correspond to this value, may be found by reference to the prediction table of Benedict and Root.

In the use of this method it is necessary to guard against two major sources of error. Benedict and Root pointed out the interfering effect of sweating on the one hand; and of lowering the skin temperature by undue exposure, on the other hand. If water in the liquid state (sweat) leaves the body, weight will be lost but heat will not. The water must be evaporated in order to remove heat. Hence an insen-

TABLE 4

Effect of sweating on insensible loss of weight

\begin{tabular}{|c|c|c|c|c|c|}
\hline \multirow{2}{*}{ Date } & \multirow{2}{*}{$\begin{array}{c}\text { Insensible } \\
\text { loss per } \\
\text { hour }\end{array}$} & \multicolumn{2}{|c|}{$\begin{array}{c}\text { Environ- } \\
\text { mental tem- } \\
\text { perature }\end{array}$} & \multirow{2}{*}{$\begin{array}{c}\text { Environ- } \\
\text { mental } \\
\text { humidity, } \\
\text { average } \\
7 \text { a.m. to } \\
7 \text { p.m. }\end{array}$} & \multirow{2}{*}{ Remarks } \\
\hline & & $\underset{\text { mumi- }}{\text { Maxi- }}$ & $\begin{array}{c}\text { Aver- } \\
\text { age }\end{array}$ & & \\
\hline & grams & ${ }^{\circ} \mathrm{F}$ & ${ }^{\circ} \mathrm{F}$. & per cent & $\cdot$ \\
\hline June 29. . & 69 & 62 & 60 & 98 & Comfortable day \\
\hline June $30 .$. & 85 & 78 & 68 & 73 & \\
\hline July $1 \ldots$ & 92 & 82 & 73 & 72 & Sweat drips from subject \\
\hline July $2 \ldots$ & 99 & 82 & 75 & 74 & Sweat drips from subject \\
\hline July $3 \ldots$ & 80 & 86 & 78 & 78 & Fan. No visible sweat \\
\hline July $4 \ldots$ & 78 & 84 & 74 & 76 & Fan. No visible sweat \\
\hline July $5 \ldots$ & 70 & 77 & 66 & 70 & Comfortable day. \\
\hline
\end{tabular}

sible loss that includes sweat will be too great when used as a measure of heat loss. Contrawise, when the skin is cold, less than the usual amount of heat will be removed by vaporization and the per cent of heat lost by that method will accordingly be less than the assumed amount. Hence it is necessary that the subject be consciously neither hot nor cold. The ideal skin temperature for this method of determining heat elimination has not yet been worked out.

In order to study the influence of sweating, an obese but otherwise

"The subject was weighed by the "silk" scales (1), which is accurate to ten grams. The excreta and drinking water were weighed on a balance accurate to one gram. The individual items of food were weighed to one-tenth gram, and the total for the day recorded to one gram. 
normal woman, was confined to bed for a number of days. During this time persons were employed to watch her continuously so that we could be sure that no irregularities in our plan of investigation occurred. The average of four determinations of the basal rate gave 1935 calories for twenty-four-hours. During the period in question, the weather was cool the first day but became progressively hotter and wetter during the next four days. The hourly insensible loss of weight was correspondingly higher on each succeeding day until a large electric fan was directed at the subject. The unavoidable sweating which had been marked on July 1 st and 2nd, ceased and the insensible loss of weight declined sharply. The data will be found in table 4.

TABLE 5

Effect of exposure on insensible perspiration

\begin{tabular}{|c|c|c|c|}
\hline Date & $\begin{array}{c}\text { Hourly } \\
\text { insensible loss }\end{array}$ & $\begin{array}{l}\text { Total calories } \\
\text { for } 24 \text { hours } \\
\text { predicted from } \\
\text { insensible loss }\end{array}$ & $\begin{array}{l}\text { Basal calories } \\
\text { for } 24 \text { hours by } \\
\text { Tissot method }\end{array}$ \\
\hline & grams & & \\
\hline January 12. . & 62.7 & 2,350 & 1,854 \\
\hline January $14 \ldots \ldots$ & 48.5 & 1,900 & 1,740 \\
\hline January $15 \ldots$ & 34.5 & 1,550 & 1,657 \\
\hline January $16 \ldots$ & 53.0 & 2,050 & 1,658 \\
\hline January $17 \ldots$ & 38.6 & 1,650 & 1,674 \\
\hline January $18 \ldots$ & 34.5 & 1,550 & 1,715 \\
\hline January $19: \ldots \ldots \ldots \ldots \ldots \ldots$ & 31.6 & 1,450 & 1,683 \\
\hline
\end{tabular}

When the environmental temperature is low, the same per cent of heat is lost by evaporation provided the skin temperature is kept sufficiently high by means of clothing, but when the skin temperature, due to exposure, falls below the critical level (still to be determined) less than the usual amount of water is evaporated from its surface. As a result, the relationship between insensible perspiration and total heat loss in the sense of Benedict and Root, no longer exists.

The interference caused by exposure was very marked in the case of one of our subjects who was allowed to be up in a wheel chair. She did not co-operate well and often was out of bed for more than an hour at a time with her legs entirely uncovered and the rest of her body insufficiently clad. In her caşe, the prediction of total calories 
from the insensible loss sometimes gave values less than the basal calories (table 5).

Some weeks later, when the basal calories were about 1550 for twenty-four-hours, the same subject was confined to bed for three days under continuous guard. Under these conditions the hourly insensible loss became an entirely satisfactory means of predicting the total heat loss, as will be seen by consulting table 6 . The predicted total calories were 25 per cent greater than the basal calories.

Under carefully controlled conditions, we have determined the insensible perspiration for a series of consecutive twenty-four hour periods.

The subject was a normal man, thirty-two years old, who understood the nature of the investigation and whose co-operation was ideal.

TABLE 6

Total heat loss predicted from insensible perspiration when cooling of skin was prevented

\begin{tabular}{|c|c|c|c|}
\hline 1 & Date & $\begin{array}{c}\text { Hourly } \\
\text { insensible loss }\end{array}$ & $\begin{array}{l}\text { Total heat } \\
\text { elimination }\end{array}$ \\
\hline & & grams & $\begin{array}{c}\text { calories for } 24 \\
\text { houts }\end{array}$ \\
\hline April $24 \ldots \ldots \ldots \ldots$. & $\ldots \ldots \ldots \ldots \ldots \ldots \ldots \ldots \ldots$ & 45.6 & 1,900 \\
\hline April $25 \ldots \ldots \ldots \ldots$ & $\ldots \ldots \ldots \ldots \ldots \ldots \ldots \ldots$ & 47.0 & 1,930 \\
\hline April 26. . . . . . . & $\ldots \ldots \ldots \ldots \ldots \ldots \ldots \ldots \ldots$ & 46.8 & 1,930 \\
\hline
\end{tabular}

In order to reduce the performance of mechanical work to a minimum, he was kept continuously in bed with the exceptions noted below. $\mathrm{He}$ was clad in flanelette pajamas and socks. The temperature of the room was kept close to $72^{\circ} \mathrm{F}$. during the day. During the night a window was open. The subject was allowed to sit up in bed during the day supported by a back rest. He occupied himself reading, playing cards and chatting. At 8:30 each morning he stepped out of bed to urinate into a weighed container and then walked to the scale a few feet away. After being weighed, he returned to bed and took off his night clothes which were weighed and returned to him. He kept his body warm with the bed covers in the interval. As a rule, he was next taken to the laboratory by means of a wheel chair. At such times he always had on a dressing gown and was protected from draughts by blankets. In the laboratory he stepped from the chair 
TABLE 7

Preliminary weighings needed to obtain total heat elimination for 24 hour periods

\begin{tabular}{|c|c|c|c|c|c|c|}
\hline Date & $\begin{array}{c}\text { Subject } \\
\text { 8:40 a.m. }\end{array}$ & Food & Water & Urine & Stool & Remarks \\
\hline 1929 & grams & grams & grams & grams & grams & \\
\hline January $9 \ldots$ & 60,370 & 2,127 & 602 & 1,705 & 321 & \\
\hline January $10 \ldots \ldots \ldots \ldots \ldots$ & 59,360 & 2,359 & 688 & 1,495 & 106 & \\
\hline January $11 \ldots \ldots \ldots \ldots \ldots$ & 59,520 & 2,459 & 268 & 1,527 & 122 & \\
\hline January $12 \ldots$ & 59,385 & 2,356 & 724 & 2,180 & 0 & \\
\hline January $13 \ldots$ & 59,210 & 2,356 & 300 & 1,194 & 0 & \\
\hline January $14 \ldots$ & 59,590 & 2,355 & 368 & 1,376 & 22 & Restless night \\
\hline January $15 \ldots$ & 59,740 & 2,356 & 407 & 1,504 & 205 & \\
\hline January $16 \ldots$ & 59,785 & 2,044 & 290 & 1,585 & 187 & \\
\hline January $17 \ldots$ & 59,260 & 2,043 & 234 & 1,176 & 131 & \\
\hline January $18 \ldots$ & 59,235 & 2,045 & 202 & 1,382 & 107 & \\
\hline January $19 . .$. & 59,000 & 2,045 & 143 & 1,301 & 124 & \\
\hline January $20 \ldots$ & 58,765 & 2,045 & 474 & 1,557 & 0 & \\
\hline January $21 \ldots$ & 58,735 & 2,044 & 197 & 1,340 & 162 & \\
\hline January $22 \ldots$ & 58,500 & 2,046 & 103 & 1,270 & 119 & \\
\hline January $23 . .$. & 58,325 & 2,043 & 173 & 1,163 & 0 & \\
\hline January 24. . & 58,370 & 2,046 & 310 & 1,650 & 159 & \\
\hline January 25. & 58,040 & 2,044 & 223 & 1,514 & 0 & \\
\hline January 26. & 57,790 & 2,041 & 75 & 1,108 & 0 & \\
\hline January 27. . & 57,840 & 2,044 & 283 & 1,350 & 113 & \\
\hline January 28. & 57,725 & 2,044 & 119 & 1,156 & 147 & \\
\hline January $29 . .$. & 57,440 & 2,044 & 68 & 959 & 0 & \\
\hline January 30. & 57,465 & 2,060 & 159 & 1,206 & 0 & \\
\hline January $31 .$. & 57,480 & 2,068 & 193 & 1,111 & 105 & \\
\hline February $1 \ldots \ldots \ldots \ldots$ & 57,515 & 2,042 & 147 & 1,422 & 0 & \\
\hline February $2 \ldots \ldots \ldots \ldots$ & 57,245 & 2,046 & 0 & 1,334 & 85 & \\
\hline February $3 \ldots \ldots \ldots \ldots \ldots$ & 56,815 & 2,044 & 166 & 905 & 0 & \\
\hline February $4 \ldots \ldots \ldots \ldots$ & 57,100 & 2,044 & 88 & 1,236 & 188 & \\
\hline February $5 \ldots \ldots \ldots \ldots \ldots$ & 56,875 & 2,046 & 74 & 985 & 0 & \\
\hline February $6 \ldots \ldots \ldots \ldots \ldots$ & 56,940 & 2,044 & 121 & 1,340 & 0 & \\
\hline February $7 \ldots \ldots \ldots \ldots$ & 56,815 & 2,044 & 249 & 1,257 & 0 & \\
\hline February $8 . \ldots . \ldots$ & 56,930 & 2,046 & 200 & 1,360 & 300 & \\
\hline February $9 \ldots \ldots \ldots \ldots \ldots$ & 56,585 & 2,043 & 134 & 1,308 & 60 & \\
\hline February $10 \ldots \ldots \ldots \ldots$ & 56,435 & 2,046 & 430 & 1,696 & 0 & \\
\hline February $11 \ldots$ & 56,345 & 2,044 & 73 & 1,274 & 0 & \\
\hline February $12 \ldots$ & 56,310 & 2,045 & 86 & 1,180 & 361 & \\
\hline February $13 \ldots \ldots \ldots$ & 55,960 & 2,045 & 0 & 1,132 & 0 & \\
\hline February $14 \ldots \ldots \ldots \ldots$ & 55,980 & 2,043 & 117 & 1,326 & 0 & \\
\hline February $15 \ldots \ldots \ldots \ldots$ & 55,975 & 2,034 & 43 & 1,106 & 288 & \\
\hline
\end{tabular}

to the bed attached to the delicate balance in order to permit the determination of the insensible loss in the basal state or to measure 
TABLE 8

Predicted heat elimination for 24 hour periods

\begin{tabular}{|c|c|c|c|c|c|}
\hline \multirow{2}{*}{ Date } & \multicolumn{2}{|c|}{ Corrected weight } & \multicolumn{2}{|c|}{ Insensible loss } & \multirow{2}{*}{$\begin{array}{c}\text { Total } \\
\text { calories } \\
\text { predicted }\end{array}$} \\
\hline & $\mathbf{I}$ & II & Total & Hourly & \\
\hline 1929 & grams & grams & grams & grams & \\
\hline January $9 \ldots$ & 63,099 & 61,386 & 1,713 & 71.4 & 2,630 \\
\hline January $10 \ldots \ldots \ldots \ldots \ldots \ldots$ & 62,407 & 61,121 & 1,286 & 53.6 & 2,130 \\
\hline January $11 \ldots \ldots \ldots \ldots \ldots$ & 62,247 & 61,034 & 1,213 & 50.5 & 2,040 \\
\hline January $12 \ldots \ldots \ldots \ldots \ldots$ & 62,465 & 61,392 & 1,073 & 44.7 & 1,860 \\
\hline January $13 \ldots \ldots \ldots \ldots \ldots \ldots$ & 61,862 & 60,784 & 1,078 & 44.9 & 1,870 \\
\hline January $14 \ldots \ldots \ldots \ldots \ldots \ldots$ & 62,313 & 61,138 & 1,175 & 49.0 & 1,990 \\
\hline January $15 \ldots \ldots \ldots \ldots \ldots \ldots$ & 62,503 & 61,494 & 1,009 & 42.0 & 1,775 \\
\hline January $16 \ldots \ldots \ldots \ldots \ldots \ldots$ & 62,119 & 61,032 & 1,087 & 45.3 & 1,880 \\
\hline January $17 \ldots$ & 61,537 & 60,542 & 995 & 41.5 & 1,760 \\
\hline January $18 \ldots \ldots \ldots \ldots \ldots$ & 61,482 & $-60,489$ & 993 & 41.5 & 1,760 \\
\hline January $19 \ldots \ldots \ldots \ldots$ & 61,188 & 60,190 & .998 & 41.6 & 1,760 \\
\hline January $20 \ldots \ldots \ldots \ldots \ldots \ldots$ & 61,284 & 60,292 & 992 & 41.0 & 1,745 \\
\hline January $21 \ldots \ldots \ldots \ldots \ldots \ldots$ & 60,976 & 60,002 & 974 & 40.6 & 1,740 \\
\hline January $22 \ldots \ldots \ldots \ldots \ldots \ldots$ & 60,649 & 59,714 & 935 & 39.0 & 1,680 \\
\hline January $23 . .$. & 60,541 & 59,533 & 1,008 & 41.6 & 1,760 \\
\hline January $24 \ldots$. & 60,726 & 59,849 & 877 & 36.5 & 1,610 \\
\hline January $25 \ldots \ldots \ldots \ldots \ldots \ldots \ldots$ & 60,307 & 59,304 & 1,003 & 41.7 & 1,760 \\
\hline January $26 . \ldots \ldots \ldots \ldots \ldots \ldots$ & 59,906 & 58,948 & 958 & 39.9 & 1,715 \\
\hline January $27 \ldots$ & 60,167 & 59,188 & 979 & 40.8 & 1,730 \\
\hline January $28 \ldots$ & 59,888 & 58,743 & 1,145 & 47.7 & 1,950 \\
\hline January $29 . .$. & 59,552 & 58,424 & 1,128 & 47.0 & 1,930 \\
\hline January $30 . .$. & 59,684 & 58,686 & 998 & 41.6 & 1,760 \\
\hline January $31 \ldots$ & 59,741 & 58,731 & 1,010 & 42.1 & 1,780 \\
\hline February 1.... & 59,704 & 58,667 & 1,037 & 43.1 & 1,815 \\
\hline February $2 \ldots \ldots \ldots \ldots \ldots \ldots$ & 59,291 & 58,234 & 1,057 & 44.0 & 1,840 \\
\hline February $3 \ldots \ldots \ldots \ldots \ldots$ & 59,025 & $.58,005$ & 1,020 & 42.5 & 1,790 \\
\hline February $4 \ldots \ldots \ldots \ldots$ & 59,232 & 58,299 & 933 & 38.8 & 1,680 \\
\hline February $5 \ldots \ldots$ & 58,995 & 57,925 & 1,070 & 44.5 & 1,855 \\
\hline February $6 \ldots \ldots \ldots \ldots \ldots$ & 59,105 & 58,155 & 950 & 39.6 & 1,705 \\
\hline February $7 \ldots \ldots \ldots \ldots \ldots \ldots$ & 59,108 & 58,187 & 921 & 38.3 & 1,665 \\
\hline February $8 \ldots \ldots \ldots \ldots$ & 59,176 & 58,245 & 931 & 38.8 & 1,680 \\
\hline February $9 \ldots \ldots \ldots \ldots$ & 58,762 & 57,798 & 964 & 40.2 & 1,720 \\
\hline February $10 \ldots \ldots \ldots \ldots$ & 58,911 & 58,041 & 870 & 36.3 & 1,600 \\
\hline February $11 \ldots \ldots \ldots \ldots$ & 58,462 & 57,584 & 878 & 36.6 & 1,610 \\
\hline February $12 \ldots \ldots \ldots$ & 58,441 & 57,501 & 941 & 39.2 & 1,700 \\
\hline February $13 \ldots \ldots \ldots \ldots$ & 58,005 & 57,112 & 893 & 37.2 & 1,630 \\
\hline February $14 \ldots \ldots \ldots \ldots \ldots \ldots$ & 58,140 & 57,296 & 844 & 35.2 & 1,570 \\
\hline February $15 \ldots \ldots \ldots \ldots \ldots \ldots$ & 58,052 & 57,064 & 988 & 41.0 & 1,745 \\
\hline
\end{tabular}


the basal metabolic rate by the Tissot method. Thereafter he was taken back to bed and remained there until the next morning except when he got up to urinate or defecate. The weights of the food, water, urine and stool for each twenty-four-hour period, were recorded to one gram.

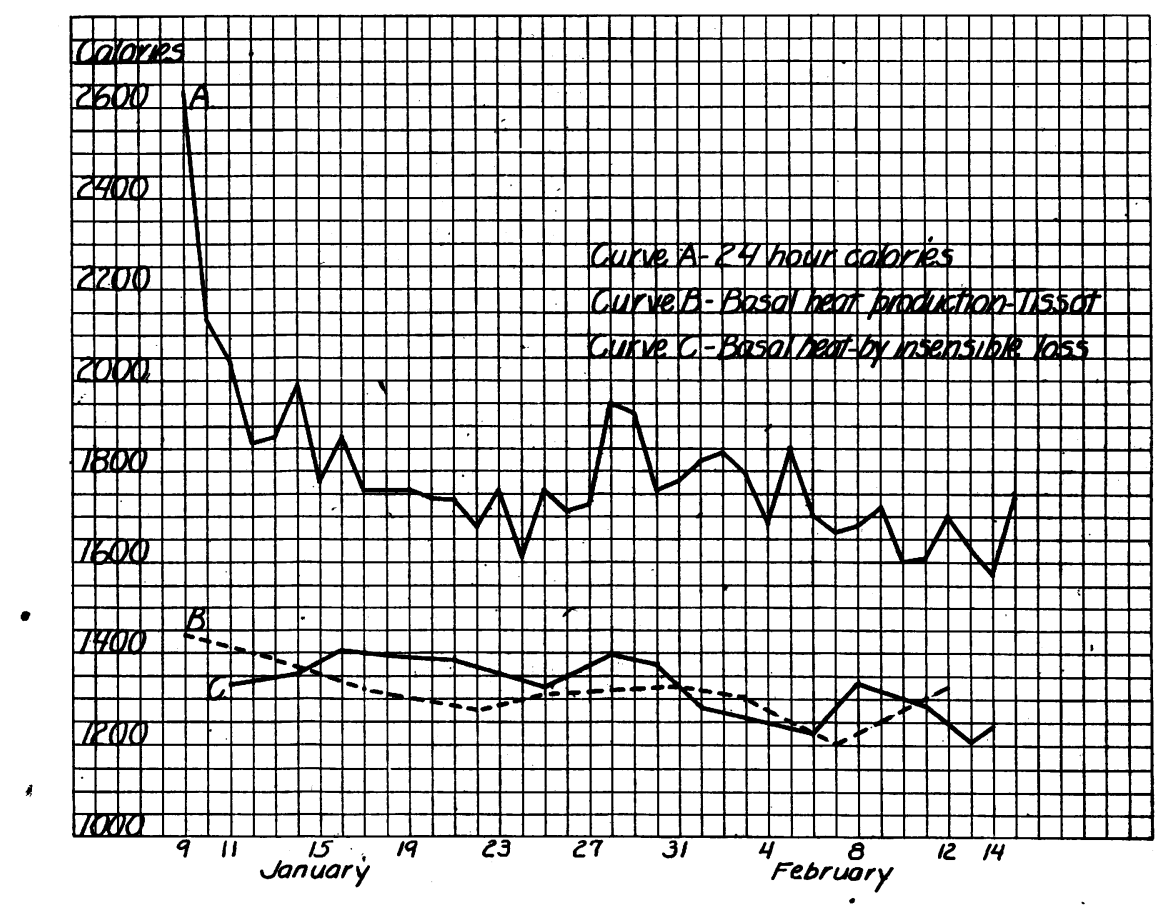

Fig. 1. Shows the Close Agreement Between Basal Metabolic Rate Determined by the Tissot Method (broken line $B$ ) and Calculated From the Hourly Insenstble Loss OF-Weight (SOLID LINE $C$ )

The upper line A shows the total twenty-four hourly heat production obtained by means of the insensible loss.

The data of the last period of this study are presented in detail. The period began at 8:40 a.m. on January 9 and ended at 8:40 a.m. on February 16, 1929. From January 9th through January 15th the subject received a diet containing 2091 calories and intended to furnish the energy required for maintenance. Thereafter the diet contained 1078 calories. The daily record of the weights of the subject and of 
the "sensible" ingesta and excreta are contained in table 7. Table 8 contains the corrected weight of the subject at the beginning and end of each twenty-four-hour period. The subtraction of the second from the first corrected weight gives the insensible loss for each twentyfour-hours (column 4). In order to conform to the prediction table of Benedict and Root this has been converted into "loss per hour." In the last column the total heat eliminated, predictable from the hourly insensible loss, has been set down.

In figure 1, the total twenty-four-hourly heat elimination is plotted together with the basal calories for twenty-four-hours obtained by the Tissot method. It will be seen that in general the total heat elimination shows the expected relationship to the basal metabolic rate. It is roughly 30 per cent greater. That is about the difference one anticipates between the total and basal calories for persons in bed. In the middle of the period (January 29 to January 30) there is an increase in both total and basal heat production. At this time the subject was visited by a person of the opposite sex in whom he had a deep interest.

It is further interesting to note the rapid fall in total heat production during the first three days in bed. It is apparent that during this time he accustomed himself to the enforced quiet. From then on, the maximal variation in total calories was 420 calories which represents approximately 25 per cent of his average outgoing calories. It is not unreasonable to believe that under these conditions, this variation may be entirely accounted for by different amounts of activity. Since there was a declining heat production coincident with a decrease in weight, this variation becomes less significant.

This series of observations demonstrates the applicability of this method to the determination of the total twenty-four-hourly heat elimination.

\section{CONCLUSIONS}

The statement of Benedict and Root that the basal metabolic rate may be accurately predicted from the basal insensible loss of weight has been confirmed.

The principle has been modified so that it may be satisfactorily used to measure the total heat production of human subjects, if pre- 
cautions are taken to prevent either sweating or cooling of the skin below the critical temperature.

\section{BIBLIOGRAPHY}

1. Benedict, F. G., and Root, H. F., Arch. Int. Med., 1926, xxxviii, 1. Insensible Perspiration: Its Relation to Human Physiology and Pathology

2. Soderstrom, G. F., and Du Bois, E. F., Arch. Int. Med., 1917, xix, 931. The Water Elimination through Skin and Respiratory Passages in Health and Disease.

3. Benedict, F. G., Carnegie Pub. No. 77, 1907. The influence of Inanition on Metabolism.

4. Levine, S. Z., and Wilson, J. R., Am. J. Dis. Child., 1926, xxxiii, 204. Respiratory Metabolism in Infancy and in Childhood. IV. Elimination of Water through the Skin and Respiratory Passages.

5. Levine, S. Z., and Wilson, J. R., Am. J. Dis. Child., 1928, xxxv, 54. Respiratory Metabolism in Infancy and in Childhood. VII. Elimination of Water through the Skin and Respiratory Passages of Infants.

6. Isenschmid, Med. Klin., 1918, xiv, 1128. Die Bestimmung der wasserbilanz am Krankenbett. 